\title{
France seeks five-year research agreements
}

Paris. François Fillon, France's minister for higher education and research, announced last week that the government intends to develop a new national science strategy. At its centre will be a system under which the ministry will enter into five-year contracts with all public research organizations, defining fixed objectives and the means to achieve them.

According to Fillon, the main lines of the new strategy will emerge from a "national consultation" on research priorities, which was also launched last week. This exercise — based on a similar exercise carried out by President François Mitterrand's first research minister, Jean-Pierre Chevènement, in the early 1980 s - will probably culminate next spring in a series of regional meetings, a national colloquium and a debate in the National Assembly.

Fillon says that the new strategy will put greater emphasis on the social, economic and military applications of research; he has already said, for example, that aeronautics research will get more money. Another aim, he says, is to make research organizations such as the National Centre for Scientific Research (CNRS) more accountable to government

"One important change is that we will not, for example, be able to provide CNRS with everything that its researchers want", says Bernard Decomps, director general of the ministry of higher education and research. Decomps says the ministry intends to list research priorities in order to make spending decisions.

The French government is unlikely to use the five-year contract system to increase central control over science; indeed, it claims that its goal is to give research organizations greater autonomy.

But there is also uncertainty over whether the Ministry of Finance will let Fillon allocate five-year budgets, as these would be incompatible with the requirement that all public spending be authorized annually by parliament. "The contracts will need a clause "on reserve of budget", admits Decomps, although he points out that the ministry has honoured similar four-year contracts with the universities.

Fillon argues that, if the French parliament endorses his plans, this will strengthen his hand in negotiations with the finance ministry, which has already accepted pluriannual commitments in other areas such as defence -- which need long-term planning.

Without such assurances, the new contractual arrangement would become little more than a five-year rolling plan. Nonethe- less, science administrators such as Pierre Papon, a former director of the CNRS who is now president of the marine research agency IFREMER, claim that the move is in the right direction, particularly because it would help research organizations with their medium-term planning.

Observers also point out that the impact of a five-year contract would be reduced if the Ministry of Finance is not persuaded to give research organizations greater say in the way they spend their budgets. At present, because parliament approves not only the annual budget but also the proportion spent on investment, salaries, overheads and so on, organizations such as the CNRS cannot increase spending on one area by cutting it elsewhere.

Budgetary freedom could also be crucial if research organizations are to subcontract research to individual laboratories, as the government promised in its election manifesto earlier this year.

Such a move would allow researchers to choose how to reach, for example, an agreed level of activity and publication. At present, a laboratory must spend fixed proportions of its annual budget on recruiting postgraduates, buying equipment and so on, and cannot hold over unspent money to the following year.

Declan Butler

\section{Berlin plans major cuts in student numbers}

Berlin. The government of Berlin is to cut back drastically on the number of student places offered by the city's universities over the next ten years. The proposed reductions are part of a law passed last month which aims to improve the overall efficiency of the universities.

Under the new law, Berlin's Free University, which now has 60,000 students, will lose 10,000 places, and the Technical University will lose 4,500 out of 40,000 students. Each university will also be required to reduce the number of teaching positions by an equivalent amount. But the Humboldt University in East Berlin is, as a former East German university, being given different treatment, and will in fact grow.

The 115,000 student places now offered by Berlin's three universities represents eight per cent of Germany's student population. But the number of registered students in the city is far higher. German law makes it difficult to turn down applications from any students who have the school-leaving certificate, the Abitur, and as a result about 150,000 students crowd Berlin's classrooms.

Manfred Ehrhardt, science minister for the reunified city which has only 4.4 per cent of the country's population, says that it can no longer afford to carry an unfair share of responsibilities. During the Cold War,
Berlin's strategic position meant that it enjoyed special financial support from the federal government which covered about half of its operating costs. Now, like all other Länder, it is being required to take full financial responsibility for education.

Despite the planned cuts, Berlin will still offer a relatively high proportion - six per cent - of the country's student places. The universities will be making their own decisions about where the cuts will fall. The Free University is expected to make most of the reductions in humanities departments. But the science faculty, in which about one third of all students are registered, will not go untouched. The university expects to leave between 100 to 200 academic positions empty as these become vacant.

The new law will penalize students who spend too long at university. A surcharge of DM100 (US\$63) per semester will be made to students who continue their studies more than four semesters beyond the recommended course length, which averages eight semesters. This figure will rise to DM600 after 20 extra semesters.

At the same time as cutting back on student numbers, Berlin is falling into line with government policy and adding nearly 9,000 places within its more technically oriented higher education establishments, the Fachhochschulen. And its newly established Berufsakademie, a college offering intensive vocational training, hopes to increase its student numbers from 170 to 600 .

Although the expansion of German universities in the 1960s took place under the banner of "equality and excellence", Ehrhardt says there has been more of the first than the second. He also admits that he would have liked to take his reforms much further, expressing admiration for Saxony's education and research minister, Hans-Joachim Meyer, who introduced much more radical university reforms in July which push his east German Land towards an élite educational system (see Nature 364, 563; 1993).

As a step in this direction, Ehrhardt has given Berlin's universities the right to admit only students who demonstrate a relatively strong performance in the Abitur in particular subjects, rather than having to accept an average, across-the-board grade.

The universities are now voting on this change. But Ehrhardt says he recognizes that, given the strong socialist presence in the city government, it is unlikely to accept a system similar to Saxony, where each department can now stipulate precise entry requirements. 